\title{
Structural Factors Impeding Good Relations between Iran and the United States
}

\author{
Adam Tarock (Ph.D) ${ }^{1}$
}

\begin{abstract}
Iran and the U.S. have been in apolitically and economically costly fight for decades. During this period all mediations to resolve their differences have failed. This is because instead of resolving all their differences in an all-encompassing agreement, they have instead opted to resolve their problems separately. These problems stem from the fact that since the end of the Cold War, the U.S. has mostly been acting as the sole arbiter and judge of international affairs. Also, since then the U.S. has shown less tolerance towards lesser states such as Iran. The two countries hold sharply different perspectives, among others, as how to maintain and manage the security of the Persian Gulf region, the humiliation that each has suffered at the hand of the other; the clash of cultures, as each country claims the status of being 'exceptional 'has led to the long-held estrangement between them.
\end{abstract}

Key words: clash of perspectives, clash of culture, humiliation, personal insults, Israel

The Islamic Republic of Iran and the United States have been in acrimonious conflict for the past forty-two years. During that period, they have also often been on the verge of full-blown military confrontation. The deep hostility that has existed between them can sometimes appear as a Manichaean struggle, a perpetual battle between darkness and light. Another way to illustrate the depth of the hostility is to compare, briefly, the relationship between Washington and its archrival, the Soviet Union, during the Cold War era. The conflict between the latter two countries had become a matter of life and death; it was depicted as a Manichaean fight between 'Godly' America and the 'Godless' Soviet Union. But unlike the rivalry between the two global superpowers, the conflict between Iran and the U.S. has been between a sole superpower (in factempire) and a regional, albeit influential, Third World country. Yet the intensity of enmity that has governed the relations between Washington and the Islamic Republic is hard to understate as has been the thorough hdehumanisation of Iran in the minds of the American public. The extent and the intensity of the dehumanisation can only be compared with what the former Soviet Union endured during the Cold War - except that the latter posed a real threat to the United States then.

Under President Donald Trump's administration, however, the antipathy between Washington and Teheran has heightened even further than was the case under his predecessors. For instance, in the bygone era, the leaders of neither superpower hurled personal insults at the other, neitherdid even the lower officials of the rival power, as have the Iranian and American leaders done in recent years (more of this later). The relations between the two states are so hostile at the present that military confrontation between them is no longer a remote possibility. In fact, the two came very close to a full-fledged conventional military confrontation when a U.S. missile killed a much loved top Iranian general, Qassem Soleimani, as he was leaving Baghdad airport for Iran in February 2020, and Iran retaliated by shooting at a U.S. vessel in the Persian Gulf. What probably prevented a war was President Trump's apparent aversion to undertaking a new military adventure in the Middle East, or, more likely, the U.S. presidential election late in 2020.

The confrontational posturing that the Trump administration has adopted towards Iran is unnecessary and indeed unfortunate for the interests of both countries. The signing of the Iran nuclear deal in 2015 favoured the West, despite President Trump's claim to the contrary, and gave great hopes and expectations that Teheran and Washington would hence gradually resolve their old differences. Other signatories to the agreement were Great Britain, France, Germany, Russia and China. Additionally, the agreement, officially called the Joint Comprehensive Plan of Action (JCPOAC), was ratified by the United Nations. It was hoped that the nuclear deal would also usher in long peace and stability in the Middle Eastand beyond. However, those expectations were shattered when President Trump abrogated, in 2017, the Iran nuclear deal, calling it the worst agreement the United States has ever signed. In abrogating the agreement, he said he wanted to renegotiate a new deal with Iran, but Teheran has refused to oblige him. To coerce Iran into renegotiating

\footnotetext{
${ }^{1}$ Adam Tarock $(\mathrm{PhD})$ has published,in referred international journals, numerous articles on the Middle East and Central Asia, as well as on the U.S. foreign policy in the two regions. He is also the author of Superpowers' Involvement in the Iran-Iraq War (1998),and Iran's Foreign Policy since 1990 (1999). He has also taught politics at the University of Melbourne, Australia.
} 
a deal, the administration escalated the then existing sanctions against Iran and later even applied what he called "maximum pressure." In response, Iran adopted a policy of what it called "maximum [national] resistance."

It is hard to predict how long the Iranians can, or are prepared to, resist the maximum pressure. But it is very likely that they will resist it for a long time, for a number of reasons. For the Iranians, the price of nonresistance could prove to be higher than the price of resistance.

First, they know that to bring about a new government through a sociopolitical upheaval would bring them yet more years of instability and hardship - after having already experienced so much economic and political hardship and loss of lives. Second, the people also know that a change of regime engineered by outside maximum pressure would not necessarily bring them either democracy or prosperity. History has shown that the change of a regime in other Middle Eastern countries has not produced encouraging results. Third, despite decades of very harsh sanctions, and notwithstanding the government's violation of human rights, lack of free speech, lack of independent political parties and lack of gender equality, the Islamic Republic has nevertheless succeeded in achieving some measures in such fields as telecommunications, education, agriculture, urban development, industrialization, healthcare centres, road construction, and, yes, military technology including missiles and advancement in nuclear know-how.

This article is an analytical and cognitive study of the relations between the Islamic Republic of Iran and the United States. It tries to pose a number of questions and attempts to explain why Teheran and Washington remain enemies even decades after the fall of the monarchy in Iran. The main contention of the present study is that relations between the two countries would very likely remain hostile as long as the structural factors discussed here remain - regardless of who will occupy the White House in 2021.This study will investigate the root causes for the Iran-U.S estrangement, despite the many attempts made by both sides for reconciliation. It will be argued that the Trump administration's rejection of the Iran nuclear deal was an indication and symptom of deep-rooted problems that have prevented good relations between the two countries. These symptoms have included their different perspectives on how and who should participate in maintaining the security of the Persian Gulf; the framework for conducting global geopolitics; the national psychological hurts that each side has over the years inflicted, deliberately or not, the imagined and inflated threat posed by Iran, the cerebral hatred that the leaderships in both countries bear for the other; and the elephants in the room(i.e., Saudi Arabia and Israel) that have been impeding factors in a rapprochement between Teheran and Washington. And, finally, the article will discuss the negative impacts that the demise of the Soviet Union has had on Teheran's ties with Washington,

\section{Root causes of Iran-U.S. hostility}

In the modern history of international relations, it is hard to find a leader of the most powerful state in the world threatening a much lesser state with the language of fire and fury, as has President Trump done in the case of Iran."Never, ever," the president said, "threaten [in fact Iran did not threaten, nor is it in a position to do so] the United States again or you will suffer consequences the likes of which few throughout history have ever suffered before" (Engelhardt, 2020) In other words, you will be obliterated. That illustrates the depth of anger that exists between the two countries. How did they get to that low level in their relationship? To answer that question, we need to provide a short historical background.

Since the end of World War II and up to the Iranian revolution in 1979, Iran and the United States enjoyed a very close relationship. Iran was then the closet, after Israel, political and geostrategic ally of the U.S. in the Middle East. For reasons that will be explained later, the Iranian people did not, at the time, share the government's so favourable sentiments towards the U.S., given their bitter memories of foreign interventions (i.e., Britain and Russia/Soviet Union) for more than a century. In any case, the Iranian revolution ruptured that relationship and the events (more of the events later) that followed opened wounds so deep, particularly on the U.S. side, that they are still unhealed, The U.S. political elites are still angry and wondering how they "lost" Iran and feel bitter about it; a bitterness not dissimilar to when America "lost" China decades earlier. The revolution ended the U.S. domination of Iran; worse, as Washington saw it, it badly and deeply indented (though for a short period) Washington's influence and standing in the region. Since then successive U.S. foreign policy elites seem to have been either unable to come to terms with or accept, emotionally and/or cerebrally, the Islamic Republic per se. People who are unfamiliar with the troubled history of Iran and the U.S. might erroneously think that the present hostility between the two countries began with President Trump's abrogation, in 2017, of the Iran nuclear deal. In reality, however, the roots of their hostility can be traced back to the early 1940s, and particularly to the early 1950s.

.At the time, the U.S. image in the region was rather benign, anti-imperialistic and seen as a supporter of selfdetermination and national sovereignty for colonized small nations. For the United States, the region had features that 
were of greatinterest to it. First, among those interests were the free flow of oil to the West, easy access to the region's markets for U.S. investments and the defeat of communism. Also at the time the region was going through two cataclysms. One was the rise of Arab nationalism, and to a lesser extent, the appeal of communism. They appeared to threaten to dismantle the long-established autocratic and monarchical systems there. The second, related to the first, was that Arab nationalism had also strong elements of anti-Westernism and anti-Israel in particular. The U.S. found both trends disturbing and challenging to its interests.

Amidst the uncertainties and threats referred to above, Washington found great comfort in the fact that a major and powerful country in the region, Iran, a non-Arab state, also felt threatened by Arab nationalism and was ideologically and geostrategically attuned to Israel. In short, Washington at the time felt warmly towards Iran. The above assertion now sounds incongruous, given the hostilities that have marked the relations between the two countries in recent decades. In the first decade after World War II, the active presence of the U.S. in Iran proved enormously helpful to the Iranians. At the time, Iran and the Soviet Unionhad found themselves entangled in a geopolitical conflict that had turned into an international crisis. Briefly, the story is that the Soviet Union, which, along with Britain and the United States, had occupied Iran during the war, had refused to evacuate the country six months after the end of the war, as the occupying powers had agreed. But Moscow had failed to honour its agreement; worse, it was supporting a leftist secessionist movement, which it was fostering in the Iranian province of Azerbaijan. The Russian policy towards Iran was to seek two objectives. The first was to annex the Iranian province to the Soviet Union. The second was to secure from the Iranian government concessions for oil exploration in Iran, if achieving the first objective could not be realized.(Gasiorwski, Byrne, 2004)In the end, the Soviets and Iranians resolved their differences without the latter giving in to the former's demands, but that was achieved after much behind the scenes diplomatic pressure put on the Soviets by the U.S. The Azerbaijan crisis was perhaps one, if not the first, of the Cold War conflicts between the two superpowers. In addition to appreciating the U.S for helping Iran maintain the province, the American presence in Iran was also welcomed as a counterweight to Britain's long-standing deep influence, in fact meddling in the internal affairs of Iran. In summary, at that juncture of history, the 1940s, the U.S. prestige and political standing among the Iranian public was at its peak.

But the cozy relationship between the two countries took a sudden dramatic turn for the worse when the U.S., in collaboration with the British, overthrew the democratically elected government of Mohammad Mosaddeq in a military coup in August 1953.Much has been said and written about the disastrous after math of the coup for Iran as well as for the Middle East and in fact beyond. So, there is no need to elaborate on that event here. For the purpose of this article, however, it is necessary to mention briefly that from then onward to the time of the revolution, Iran had become one of the strongest and reliable partners of the U.S. as a political and military bastion against the Soviet Union in the region. To the U.S. political establishment, however, the Iranian revolution has since been a major impediment for better relations with Iran.

The revolution, it should be recalled, replaced a U.S. compliant state with a political system which was, simultaneously fervently Islamist and nationalist, meaning, for example, that in regional security matters where non-regional states were involved, the Islamic Republic would not participate. Not only that, Iran has since strongly rejected and vehemently opposed regional states that sign military pacts with Western powers. Although Washington was unhappy with Iran for refusing to participate in Western sponsored military pacts, it was Iran's opposition to and agitation against the security agreements that regional powers had concluded with the United States that has troubled Washington. The shape and form of the Persian Gulf security arrangement is a major impeding factor that continues to divide the two countries. The irony is that the more Iran has tried to make the Arab states distance themselves from of the U.S., the more they have felt threatened by their non-Arab neighbour. And so they have sought closer protection from Washington. The Iranian opposition to and distrust of the West have deep roots in the bitter experiences they have had with the major world powers. To sum it up, the first decade of the republic's life was spent fighting back Iraq's invasion and struggling to survive. The fact that the West sided strongly with Saddam Hussein, left a very negative impact on the Iranians' perception of the West and that, in turn, has since been reflected on their dealing with the outside world. Still, other events of great significance were awaiting the new republic.

\section{History has been unkind to Iran}

Revolutions do not happen in a vacuum. There are many factors such as cultural, political and economic, among others, which bring about the conditions for revolution. Also, the time, the place, the scope and the direction of a revolution are often not the choosing of the architects of the revolution who are generally idealistic and romantic, at least in the early stages of the revolution. And the Iranian revolution has been no exception. Also, history has shown that the time of the birth of a revolution has a great bearing on the success or failure of it. Looking back at the Iranian revolution, one cannot but feel that international events that took place then and hence have impacted unfavorably on the country. To 
put it differently, had the revolution been born in a different period, it might have proved more successful. As it happened, the revolution coincided with the coming to the White House of a very conservative and aggressive leader, Ronald Reagan, who wanted Americans to "stand tall again." To him, America under the Jimmy Carter administration had ceased to lead the world, and he wanted to reassert U.S. global power. Reagan had unveiled, in 1980, his intention to lead "a great national crusade to make

America great again....and reassert the country's global preeminence."(Bacevich, 2020).He was particularly critical of President Carter for being soft on revolutionary governments and revolutionary movements in Third World countries such as Nicaragua, Cuba, Iran and others.

The president, being a Cold War warrior, seemed to see national movements overseas as directed from Moscow and did not seem to be able to distinguish between communist movements and homegrown nationalist movements. In the U.S. perception, the Islamic Republic, from its very inception and even before the hostage crisis, constituted threat to the national security of the United States. And just as during the Cold War the threat from the Soviet Union was exaggerated, so was the perceived threat of the Iranian revolution. This inflated threat from the Islamic Republic to the security of the Middle East, indeed to the world, has continued to this day. As Patrick Porter has argued, the U.S. grand strategy of the Cold War era has remarkably persisted since the end of that era(Porter, 2018).The neoconservatives of the Reagan era have since been replaced by a new generation of likeminded politicians and strategists, except that the new ones are more focused on the Middle East than their predecessors. Had there been a less hawkish U.S. president at the birth of the Iranian revolution, he might have been more understanding and accommodating to the Iranian revolution. He would have known of the disastrous experiences and harsh history that the Iranians had experienced with foreign powers for nearly two centuries - even though Iran was never formally colonised.

History has also been unkind to the Iranian revolution in two other ways: socio-economic developments at home, and unfavourablegeo political developments abroad. Both have negatively impacted on the course of the revolution. Two factors in particular influenced, in fact forced, the country to adopt a less compromising foreign policy stance than the revolutionaries had perhaps intended to take. The first was Iraq's president Saddam Hussein, who personally had difficulty with Iran even before the revolution. But while the Shah was in power, Saddam did not dare to be militarily aggressive. When the ayatollah came to power, however, and took up the banner of Islam, Saddam panicked. The majority (sixty-five percent) of the Iraqis is Shia Muslim and, naturally enough, in matters of religion they identify with the IranianShias. So, Saddam took advantage of the chaos in the post-revolutionary Iran and massively invaded the country in September 1980, hoping to win the war within a few months. The second historical event that has proved, geopolitically speaking, just as disastrous for Iran as was Iraq's invasion, was the implosion of the Soviet Union in 1991.As it has since turned out, the demise of the Soviet Union has since proved both inauspicious and a blessing for Iran. That paradox needs a short explanation (more of this later). The fall of the Soviet Union almost paralleled the victory of the U.S. war against Iraq in the first Persian Gulf War of 1991. Following that victory, President George H.W. Bush declared that from now on, "What America says, goes."To make life more difficult, historically speaking, for the Islamic Republic, in 1992 the Pentagon in a document asserted that America's political and military position in the post-Cold War will be to ensure that no rival global superpower or regional (i.e. Iran)power(emphasis added) will be allowed to emerge in Western Europe, Asia, the territories of the former Soviet Union, or a state that may aspire for regional leadership.(Chalmers Johnson, 2006). What can now be said is that the end of the Cold War removed most of the constraints that the U.S. had on the use of coercive power when dealing with lesser states such as Iran. Victor Bulmer-Thomas has captured that aspect of U.S. foreign policy concisely and elegantly:

The end of the Cold War removed many of the constraints that had previously held back the United States from intervening abroad. As a result, interventions have been frequent under all administrations since 1990. All five presidents (Bush Sr., Clinton, Bush Jr. Obama and Trump) have used both multilateral and unilateral forms of intervention, and none of them has been unduly concerned whether their actions were consistent with international law. While there have undoubtedly been differences in the approach taken to intervention by each president, none has questioned the imperial project and the conviction that the United States is the world's leader. The "golden rule" for U.S. intervention has been multilaterally through the U.N. and therefore with the blessing of international law(Bulmer Thomas, 2018).

Or, one might add, without regard to international law and international institutions. The end of the Cold War inspired in the American political class a hubristic tendency that henceforward the concept of collective security was a mirage and American unilateralism should be, indeed must be, the order of the day, and that the international community and equality among nations was fictional, as Charles Krauthammer has put it.(Bacevich, 2013)

\section{Conflicting differences in perspectives}


With that kind of outlook and perspective, as discussed above, very little room could be left for diplomacy for settling disputes on an equal basis between a superpower and a Third World state such as Iran, No wonder that there exists wide gaps in perspectives between Teheran and Washington on issues like the security of the Persian Gulf. The question of who should be responsible for the security of that region has been a very contentious issue between the two countries.

The following Persian proverb elegantly illustrates and sums up the two countries' sharp differences on this important geopolitical issue. The proverb goes something like this: ten people can happily coexist sitting on a carpet, but two kings cannot enjoy a peaceful coexistence in a big country. By virtue of its long history and its claim to greatness and that it was once an empire at two different periods of history (Achaemenid (550-330 BCe) and Sassanian (224-651 $\mathrm{CE}$ ), the Iranians consciously feel (to borrow an American term) "exceptional" and "indispensible" in the Persian Gulf region where they control two thousand kilometres of the coastline. To put it differently, the Iranians are very conscious and satisfied with their past history and the contributions they have made to human civilization and culture. According to Paul Kriwaczek, a cultural historian of ancient Iran, Persians/Iranians particularly can never forget what they once had been. So much so that even in the land of Islam, they regularly recite with great pride the Persian national epic of Ferdowsi's poems written around the first millennium(Kriwaczek, 2002).

If we take a leap from ancient times to the present, we can see that the Iranians find it difficult to come to terms with the fact that there are now, metaphorically speaking, two kings living in the country (the Persian Gulf). Iran in particular finds this situation unsettling and insecure. Trouble is the new king, the United States, does not even want to acknowledge and accommodate the old king, Iran. Not only that, the new king has for decades been engaged in dispensing with the old king. The old king, however, is entitled to persist with the idea that there must be regional security with the participation of all other regional powers - without the participation of the outsiders, i.e., the U.S. The fact is that rightly or wrongly, Iran considers its elfas the 'first' among equals in the Persian Gulf. Iran, however, has never publically mentioned the word 'first' either during the Pahlavi regime or since. However, taking a pragmatic approach to the present geopolitical realities, Teheran has in recent decades been trying to position itself as one of the equals in any security pacts that might be formed with the other regional states. But Washington has blankly rejected the proposition that Iran could be accepted as a member state in any regional alliance/s. It should be added here that some of the regional powers, in particular Saudi Arabia, the United Arab Emirates and Bahrain, have shown their unwillingness to join multilateral security pact, if Iran is a member. The bases for Iran feeling entitled to play an active and determining role in regional security are several.

Those bases include history, culture, geographical location, the size of the population (eighty-two million), the high level of education of the population, the scientific and technological developments achieved, economic potential, the relative internal stability and a strong army - all said relative to its neighbors in the Persian Gulf. According to Dizboni and Omar, the Islamic Republic has a relative vertical (national political community) and horizontal (leadership) homogeneity combined with hybrid features of vibrant electoral and political Islam (Dizboni and Omar, 2018).It also has enormous economic potential. Its energy resources such as oil and natural gas are vast - recoverable liquid hydrocarbon stands at about 160 billion barrels of oil and 33.33 trillion cubic meters of gas, according to the Iranian National Oil Company (NIOC).(Iran Daily,2018).Also very important from geopolitical perspectives, Iran maintains a strategic stretch to Iraq, Syria, Yemen, Lebanon and Bahrain. Like Iran, these countries have either majority Shia populations or have large Shia minorities. Internationally the Islamic Republic also enjoys the support of Russia and China, both permanent members of the United Nations Security Council.

In short, when we look at the history of Iran-U.S. relations since World War II, and especially since the end of the Cold War, we cannot but conclude that the crux and essence of the two countries' difficulties has been because the United States finds it difficult to tolerate challenges from lesser states such as Iran. To say that is not to deny that the Islamic Republic has caused anguish to the U.S. or added no fuel to the tensions between the two. Still, it helps to remember that the United States has since 1960 formed and operated a grand strategy of "primacy," The strategy has had four interlocking parts: to be militarily preponderant; to reassure and contain allies; to integrate other states into U.S.designed institutions and markets; and (this has a particular relevance to our discussions here)to inhibit the spread of nuclear weapons.(Porter, 2018).In 2010, Washington reaffirmed and strengthened its claim to "primacy" by publishing a new foreign policy doctrine which sought to establish "full spectrum dominance" called Joint Vision 2010, a document put out by the Joint Chief of Staff. The purpose of it has been to achieve America's absolute mastery over the planet and by extension over America's present and future rivals such as Russia and China.(Bacevich, 2020). So, when a country such as Iran viewed by the empire "not as a normal state" and by implication not worthy of consideration, then it really leaves very little space for coexistence between the young and the old 'king, metaphorically speaking. 
As an imperial power, Russia has had a presence in the Middle East for hundreds of years. Geography allowed Tsarist Russia/Soviet Union to maintain a strong politico-military presence in that region, in Muslim Central Asia and in the Caspian Sea. All that made Russia an actual neighbour of Persia/Iran. The geographical proximity between the two countries brought with it, naturally enough, diplomatic, trade, military and cultural relations.

But it also occasioned wars between them, with Russia annexing to itself vast Persian territories in the nineteenth century. Also, there were high political tensions and even threats of war between Iran and the Soviet Union in the twentieth century. Of particular interest to us here, however, is to explore only what have been, historically speaking, the negative and positive impacts on the Islamic Republic of the demise of the Soviet Union in 1991.More relevant to our topic presently under discussion is, how has the Soviet implosion has, in turn, impacted on U.S.-Iran relations? To the Iran of the post-Pahlavi era, the demise of the Soviet Union has had two contradicting impacts. On the one hand, it was a blessing for Iran to see a powerful, expansionist neighbour disintegrate and the danger of potential war with the Soviet Union averted. Also, ideologically and culturally speaking, for the Islamic Republic the disappearance of the Soviet Union was of great significance in the sense that the Muslim populations of the former Soviet republics in Central Asia were now free from 'Godless' communism.

But the disappearance of one of the two superpowers had left Iran alone and unprotected from the aggressive policy of the other superpower, which by then had been in conflict with Teheran for more than a decade. It was the Clinton administration that labeled Iran as an "outlaw" and "rogue" state. According to Robert Litwak, former official of the National Security Council, the labeling of Iran was a "demonization strategy and the administration was "completely maniacal" about the Islamic Republic. The strategy was to get G8 and the European and Japanese allies to take the desired action against Iran. "The administration's posture towards Iran was clearly encouraged by the increased U.S. global and regional dominance as a result of both the collapse of the soviet union and the new U.S, military presence in the Middle East after the defeat of Iraq in Kuwait in 1991 (Kiriakou and Porter, 2020).In other words, the disintegration of the Soviet Union, coupled with the heightened blustering of a sole superpower, has proved unfortunate for Iran To prove that assertion, one needs to answer this question. Would the U.S. for example, have been able to put Iran under the harshest economic sanctions and threaten Washington's allies with economic punishment if they continued trading with Iran, if the other superpower still existed? Very unlikely. The wars in Afghanistan, Iraq and Syria since then are illustrations of the above assertions. The words of George H.W. Bush best reflected the U.S.'s unique power when after the defeat of Iraq in 1991, he boasted about the unparalleled power of the U.S. in the world. Iran has since borne the full impact of what the president said then: repeated threats of military action against Iran in the Persian Gulf, anti-Iran campaigns worldwide and imposition of the harshest economic sanctions. According to Andrew Bacevich, whenever Americans feel that they have had setbacks in world affairs, they fall prey to militarism and aggression. Not surprisingly, Iran has as a protective umbrella sought alliances with Russia and China, see (Tarock, 2017).

The questions are why has the U.S. for so long taken an uncompromising position towards the Islamic Republic? And why has it consistently attempted to change the government in Teheran? The most frequently answer offered by U.S. foreign policymakers and political commentators is straightforward: blame the Iranians for the estrangement between the two countries. They are the ones who are misbehaving and aggressive. That kind of answer, however, is rather simplistic and misleading. It shows just one side of the coin; the other side which is rarely shown tells a different story.

The other side of the coin that is rarely displayed in the public is the U.S. military actions in the region have unfailingly been described as retaliations, never initiated aggression. But, then, what can one call other than aggression a military coup against a democratically elected foreign government? The memory of the 1953 coup continues to anger and pain Iranians as its repercussions are still felt in Iran to this day. Didn't the U.S. act aggressively when it provided the Iraqis with intelligence about the military positions of the Iranians during the Iran-Iraq war in the 1980s? And didn't the U.S. military intelligence help Saddam Hussein use chemical weapons against the concentrations of Iranian troops? (Engelhardt, 2019a).Isn't it aggression on the part of the U.S. when the New York Times reports that the CIA has longstanding secret plans to "provoke the Iranians" to take action so that Washington would retaliate militarily? Engelhardt, 2019).And wasn't it aggression to shoot down, during the Iran-Iraq war, an Iranian airliner in the Persian Gulf killing 290 passengers, including children? And, finally, wasn't it unprovoked aggression to kill, in a drone strike, General Qassem Soleimani at Baghdad international airport as he was leaving for Teheran in February 2020? His assassination could be interpreted as a part of a scheme to facilitate the long-designed change of regime in Teheran.

The Canadian born David Ignatieff, a defender of the U.S. regime change policy, argues that "regime change is an imperial task par excellence, since it assumes that the imperial power's interest has a right to trump the sovereignty of a state...The question, then, is not whether America is too powerful but is it powerful enough"(Johnson, 2006). In other words, if, according to Ignatieff, the U.S. is "powerful enough," then it has every right to change those regimes that it 
does not approve of. For decades the question for the American government has been whether to change the Iranian regime by way of fomenting chaos and tensions in the country, or by way of military action. Choosing diplomacy, instead of military action when settling a dispute with a lesser adversary state, is traditionally not the American way of doing things.

According to some historians (Stone, 2012 andScahill, 2013), the United States for most of its history has been a militaristic country. This has become more obvious since the beginning of this century, particularly since $9 / 11$.For example, during the Cold War era ((1945-1988), large scale U.S. military interventions in other countries totaled six, but since then, the U.S. military actions overseas have reached nine major military interventions.(Bacevich,2018).

Although Iran and the U.S. have been in conflict for the best part of four decades, there have nevertheless also been times when they have attempted, unsuccessfully, to reach reconciliation. In the 1980s, 1990s and 2015 they tried to reach an understanding of their differences, but to no avail. For example, in the 1980s and 1990s, President Hashemi Rafsanjani, a pragmatic politician offered a U.S. oil company, Conoco, an oil agreement worth $\$ 1$ billion. It was hoped the agreement would facilitate an opening between the two countries. But the Clinton administration rejected the agreement on the grounds that it ran against U.S. policy towards Iran.(Safpukas,1995). Had the administration allowed it to go ahead, the history of the two countries would have been so much less antagonistic. Also, when the George W.

Bush administration invaded Afghanistan in 2001 to expelAl-Qaida, Iran helped U.S. forces against the terrorist organization. According to retired Colonel Lawrence Wilkerson, the chief of staff of Secretary of State Colin Powell, "We [the U.S.] got indispensable help [from the Iranians] to fight the Taliban in Afghanistan" (Bacevich, 2020).Interestingly enough, Iran's team leader in Afghanistan at the time, according to Wilkerson, was none other than the already mentioned General Qassem Soleimani who was assassinated by the Trump administration. The window of cooperation between Tehran and Washington came to an abrupt end when President George W. Bush in his speech to Congress included Iran in his "axis of evil."Another window of opportunity for an opening between the two countries was opened when the Iran nuclear deal was signed, a deal that President Trump abrogated. Ever since, Iran has become, as described in an article in Foreign Affairs titled, "America's Great Satan,"(Benjamin, Simon, 2019) The authors of the article have argued that historians would a hundred years from now say that the only country that has persistently been depicted as America's implacable foe was Iran. "In its official rhetoric and strategic documents, Washington has since Iran's revolution in 1979 consistently portrayed the country as a purely hostile and dangerous actor". According to the Trump administration, Iran has never ceased to act as the (emphasis added) major source of terrorism and nuclear proliferation in the region, the article argues.

\section{The humiliation factor}

No nation, particularly those that are or were once great, will take kindly to being humiliated and insulted. Oddly enough, however, Iran and the United States, both powerful nations, the former in the distant past and the latter at present, have unfailingly engaged in humbling and humiliating each other for decades. The humiliation, and the psychological hurt that it brings with it, have significantly impeded improving reconciliation efforts between the two sides. Discussions and analyses of world politics require taking into account the different personal, emotional and sensitivity of the political actors. There have over the years been many unfortunate events and exchanges of words that have shaken the confidence and trust between the Iranians and Americans. The two bitter and deeply hurtful events in the history of their relationship need highlighting here. They are the U.S.-backed military coup against the Teheran government in 1953, and the holding in Teheran in 1980 of fifty-two American diplomats as hostages for more than a year. The hostage crisis was sparked by the fear that the U.S. may try to restage a military coup and reinstall the Shah on the throne. Although those two events occurred decades ago, they are still remembered vividly with bitterness in both countries. The above assertions are clearly reflected in the fact that books and articles and official statements are to this day published in Iran about the coup of 1953 and the tragic effects that it has had on the relations between the two countries. For instance, Iranian Foreign Minister Mohammad JavadZarif, on the sixty-sixth anniversary of the CIA coup, has drawn parallels between that event and the Trump administration's current maximum economic pressure on Iran.(Alvandi and Gasiorowski, 2019) On the American side, the humiliation and hurt is reflected in President Donald Trump's tweet that in order to avenge the national humiliation \{of the hostage crisis\}, the U.S. would have targeted fifty-two cultural sitesin Iran, representing the number of American hostages once held there, according to the Washington Post(Ripley, 2010).

And after killing Soleiman in a drone strike in Bagdad in January 2020, President Trump said, "they [the Iranians] humiliate our country...Iran humiliated the United States with the capture of our ten sailors [in the Persian Gulf.)Horrible pictures and images...We are weak. I will not forget."(Ripley,2010).He used the word "humiliation" four times. Hemay be justified in his comments about the misbehavior Iran. However, he has conveniently preferred to forget the humiliation and hurt inflicted on the Iranians when, during the Iran-Iraq war in the 1980s, the U.S. brought 
down an Iranian civil airliner in the Persian Gulf, killing all 290 passengers. To add insult to injury, the naval officer who was responsible for the downing of the plane received a medal of bravery from President Ronald Reagan. During the Cold War era, leaders of the two superpowers hardly ever personally insulted their rival. Then, world leaders observed the customary diplomatic decorum and propriety.

The following examples are illustrative of how badly that diplomatic decorum of respecting one's opponent has been broken down between the Iranian and American leaders. After the assassination of Soleimani, thousands of people in Teheran and other major cities flocked into the streets to mourn his death. It could not be but an insult to the Iranians' national sensitivity when President Trump on TV called Soleimani "son of a bitch" at a rally in Milwaukee(Garner, 2020).That prompted the Ayatollah Ali Khamenei, the supreme leader, to respond by calling the president a "clown."As is well known, the Trump administration has put travel banon Khamenei, It is hard to imagine that previous U.S. administrations would have taken such a drastic measure against a Soviet leader. In addition to the impeding factors mentioned above, there has also been the elephant/s, namely, Saudi Arabia and Israel, in the room which have also been hindering factors.

\section{Iran and Israel - roots of hostility}

To explain fully the causes of the rivalry and hostility between Iran and Israel requires a full-length separate article. So, we will here confine our discussion to deal mainly with those aspects of their relations which have relevance to the topic at hand. Also, because of lack of space, Saudi Arabia will be mentioned here only if needed. As a general rule, in international relations great powers resolve and settle their differences with their adversaries without taking much notice of the views or interests of a third party. This practice has not always been observed when the U.S. has tried to settle its differences with Iran. For example, President Trump has been quoted media as saying that in reneging on the Iran nuclear deal, he had the interests of Israel at heart, "It [abrogating the nuclear deal] was the biggest thing I did for Israel."'(Tossi, 2020).The Saudis and Israelis have been encouraging, in fact urging, the U.S. for years to change the Iranian "regime," if necessary by military means. It is not mere rhetoric or hollow speculation to argue that had the two elephants, in particular Israel, been absent from the room, Teheran and Washington might have a long time ago settled their differences on most issues. Israel, it goes without saying, enjoys great political clout in the U.S. political establishment (Meirsheimer and Walt, 2007)at the expense not only of Iran but all other Middle East countries

The conflict between Iran and Israel, like the one between the United States and Iran, is primarily political and geostrategic. It is not of a religious dimension, as some commentators would have us believe. The core of the conflict between them is whether or not they have a friendly competition between them, or a cold war rivalry. Actually, their conflict began after the defeat of Iraq in the Persian Gulf War of 1991.Since then, Israel has viewed Iran as a potentially formidable challenger to its position as the "first" state, in the region, a position that it has enjoyed since the Arab-Israel War of 1967. In the Middle East, there are four countries that are in the position to exercise political influence and project military power outside their borders. They are Egypt, Turkey, Iran and Israel. Egypt has a peace treaty with Israel, and Turkey, even under President Recep Tayyip Erdogan, has diplomatic relations with Israel. As for Iran, it has said it can live with Israel, if the Palestine issue in an agreement that is satisfactory to the Palestinians. But whether or not such an agreement is ever realfised, the Islamic Republic would remain a potential challenger to Israel.

As Israel has been a crucial factor in impeding normal relations between Iran and the U.S., a short review of the Teheran-Tel Aviv relations is called for here. Prior to the Iranian revolution, they enjoyed a very close and cozy relationship in trade, investment, intelligence sharing, security and military cooperation. So, the overthrow of the Pahlavi monarchy was in many ways as much a blow to Israel's interests in the Middle East as it was to the United States. It is important to note here that after the Iranian revolution and Iraq's invasion of Iran in September 1980, Israel and the U.S. put different interpretations on what had happened in Iran and its implications for the security of the region. From the time of the revolution and even before the hostage crisis, Washington adamantly refused to recognize the new political realities in Iran. In contrast, Tel Aviv thought the new government was likely to moderateits antiWestern rhetoric overtime and would restart looking Westward. To Israel, Saddam Hussein's Iraq and Arab nationalism were more dangerous to the security of the Middle East than was he Islamic Republic. Even when Western intelligence services suspected that Iran had acquired the scientific knowledge of making the bomb, Israel seemed relaxed and philosophical about it. Israel's Prime Minister, EhudOlmert (2005-09) was reported as saying, "just as Pakistan had the bomb and nothing has happened, Israel can accept and survive Iran having the bomb."(Bergman and Mazzetti, 2019).Two events, however, have since marked an unprecedented hostility between the two countries. One was the election of Mahmoud Ahmadinejad as president of Iran in 2005; the other was the election of Benjamin Netanyahu as prime minister of Israel in 2009. 
The Ahmadinejad government argued that the West has, historically speaking, never been interested in a progressive, and scientifically and technologically advanced Iran; hence the failure of nuclear talks. That argument may sound simplistic, but at the time it resonated with the Iranians' historical consciousness and their unhappy memories of dealings with the Europeans.

The offshoot of Ahmadinejad's contention was that he accelerated the country's nuclear programme, not, he said, for producing the bomb but for the country's developmental and technological advancement. Hence the expansion and acceleration of Iran's nuclear programme during the eight years of Ahmadinejad's presidency (Porter, 2014) caused further increased tensions between Iran and the West, in particular between Iran and Israel.

What heightened the tensions between the two countries was Ahmadinejad's lack of political nuance, thus using undiplomatic language when talking about Israel or casting doubts on the history of the Holocaust. That provided good copy for the media and right-wing think-tanks in the U.S in 2009. In the meantime, Benjamin Netanyahu further inflamed the tensions with Iran by asking the U.S. Congress to prevent the "catastrophic consequences" of a nuclear armed Iran. Netanyahu's closest ally and one of his former top advisors, Uzi Arad, is quoted describing his boss as launching" a personal (italic added) crusade against the Iranian threat."(Bergman and Mazzetti, 2019).And a former senior Israeli intelligence official is also quoted as saying, "for Netanyahu, fearing Iran is a religion."(Kaye and Efron, 2020). One could add that he also launched a crusade against the Iran nuclear deal negotiated by the Obama administration and succeeded, finally, to persuade the Trump administration to abrogate it. And President Trump did it rather cavalierly. According to the media, Netanyahu and the Israel lobbies in the U.S. have been spending millions of dollars in anti-Iran propaganda with the aim of encouraging the American government to change the government in Iran, by military means if necessary.(Benjamin, and Davis,2020).Truth is that since the early 1990s, Israel has had no need for Iran as a strategic ally, as it had in the previous decades. The disappearance of Iraq as a major power in the region and the weakened Arab nationalism, have bolstered Israel's position in the Middle East. As to Israel's standing in the U.S., two well-known political scientists have correctly and succinctly described the ascendancy of Israel's political influence in the U.S. foreign policy establishment as legendary and self-evident (Mearsheimer and Walt, 2007).In summary, as long as Israel is in the Iran-U.S. 'room,' good relations between the latter two will be very difficult.

\section{Conclusion}

The Manichaean struggle between the United States and the Islamic Republic could have been avoided, if it were not because of the bad blood that had existed between the two countries for decades before the revolution. By now, their animosity is so serious that only the most optimistic observers would predict that they might reconcile their differences anytime soon, regardless who will be in the White House in 2021. Basically, their entangled and tortured relationship is not so much because they have failed to observe fully the principles of normal diplomacy over the years, rather, it is that they have not tried to tackle some of the structural factors, mentioned earlier. To tackle their problems, Washington, as a stronger and more important factor, needs to rethink seriously its policy towards Teheran. It has so far been punishing Iran for the overthrow of the pro-Pahlavi regime and for the hostage crisis. Washington now needs to use more carrots and less stick. Washington could take a page from its European allies towards Teheran and be more acceptable and accommodating towards its perceived foe.

As argued above, the Iranian revolution took place at an inauspicious historical period when the Cold War was at a high point. When the Cold War ended, Teheran found itself alone facing an unforgiving and vengeful sole superpower. So, with the major European powers and signatories of the Iran nuclear deal only verbally disagreeing but in practice acquiescing with the U.S. maximum pressure policy, Iran has assessed that its best hope for resistance is to lean more on Russia and China. And that is what Teheran has been doing rather successfully in recent years,

\section{References}

Engelhardt, Tom (15 March 2020) "Best of Tom Dispatch: Chalmers Johnson, Dismantling the Empire," www.TomDispatch.org

Gasiorowski, Mark J. and Byrne, Malcolm (2004) (editors), Muhammad Mosaddeq and the 1953 Coup in Iran, Syracuse University Press.p.204.

Bacevich, Andrew (2020) The Age of Illusions: How America Squandered its Cold War Victory, Metropolitan Books, New York, p.164

Porter, Patrick (Spring 2018) "Why America's Grand Strategy Has Not Changed: Power, Habit and the U.S. Foreign Policy Establishment, International Security, Vol.12, No.4, p.1.

Johnson, Chalmers (2006) Nemesis: The Last Days of the American Republic, Metropolitan Books, p.58. 
Bulmer-Thomas, Victor (2018) Empire in Retreat: the Past, Present and Future of the United States, Yale University Press, p.23.

Bacevich, Andrew (2013), The New American Militarism: How Americans are Seduced by War, Oxford University Press (second edition), p.84.

Kriwaczek, Paul (2002), In Search of Zorathustra: Across Iran and Central Asia to Find the World's First Prophet, Vintage Books, New York, p.10.

Dizboni, Ali G. and Omar Sofwat Omar (November 2018), "Hegemonic Aspirations and Middle East Discord: The Case of Iran, in Conflict and Diplomacy in the Middle East: External Factors and Regional Rivalry" (editor) Yannis, Stivachtis, E-International Relations Publishing, p.147.

Iran Daily, (September 2019): Official: Iran-China Trade to Reach \$24b by the End of 2018".

Porter, Patrick (Spring 2018a) p.9.

Bacevich, Andrew (2020a) p.74.

Kiriakou, John C. and Gareth Porter (2020) The CIA Insider's Guide to the Iran Crisis, pp. 28=9, Skyhorse Publishing, printed in USA.

Bacevich, Andrew (2013a), p.3.

Tarock, Adam (2013) "Russo-Iranian Relations in the Post-Soviet Era," Diplomacy and Statecraft, Vol.28, No.3.

Engelhardt, Tom (2 July 2019) "We are not the Good Guys: Why is American Aggression Missing in Action?" www.commondreams.org

Johnson, Chalmers (2006a), p.73.

18-Stone, Oliver (2012)The Untold History of the United States, Simon and Schuster. See also Jeremy Scahill(2013) Dirty Wars: The World is a Battlefield, Nation Books.

Bacevich, Andrew (2013b).

Safpukas, Agis (7 March 1995), Iran Signs Oil Deal with Conoco; First Since 1980s Break with U.S.," The New York Times.

Bacevich, Andrew (9 January 2020) “Trump Sparked Unnecessary Crisis' by Killing Soleimani, Barely Avoiding War", in an interview with Amy Goodman, www.democracynow.org.

Bacevich, Andrew (9 January 2020) "Trump Sparked Unnecessary Crisis by Killing Soleimani, Barely Avoiding War," in an interview with Amy Goodman, www.democracynow.org.

Trump's personal disdain of the Iranian leadership is such that when at a conference he was referring to General Soleimani's assassination calling him a "son of the Bitch". And the Ayatollah Ali Khamenei, the supreme leader, returned the complement by calling Trump a "clown."

Benjamin, Daniel and Simon, Steven (November/December 2019) "America's Great Satan: the Forty Year Obsession with Iran," Foreign Affairs, Vol.98, No.6, p.56.

Alvandi, Boham and Gasiorowski, Mark (30 October 2019) “The United States Overthrew Iran's Last Democratic Leader",Foreign Policy.

Ripley, Amanda (24 January 2010) "With Iran, It's About Humiliation," Washington Post, reprinted in The Age Melbourne,. p.23.

Ripley, Amanda (2010) “with Iran” Washington Post.

Garner, Kenneth (retrieved 14 January 2020), "Trump Calls Iranian General QassemSoleimani a "Son of A Bitch," htps.//nypost.com

Tossi, Sina (27 July 2020) “The Beginning of the U.S.-Iran Hot War”?,www.commondreams.org.

Mearsheimer, John J. and Walt, Steven M. (2007) The Israel Lobby and U.S. Foreign Policy, Farrar, Straus Giroux.

Bergman, Ronen and Mazzetti, Mark (2019) "The Secret History of the Push to Strike Iran," https://www.nytimes.com/2019/09/04/magazine/iran-strike-israel-america-html.

Porter, Gareth (2014) .Maufactured Crisis: the Untold Story of the Iran Nuclear Scare, Just World Books, p.34.

Bergman and Mazetti, (4 September 2019) "The Secret History...."

Dassa Kaye, Dalia and Efron, Shira (August 2020)”Israel's Evolving Iran Policy," Survival, Vol.84, issue 4, p.3.

Benjamin, Medea and Davies, Nicolas J.S. (20 May 2020) "Who are the Secret Puppet-Masters Behind Trump's War on Iran," www.commondreams.org.

Mearsheimer and Walt (2007a) The Israel Lobby.

Bibliography

Alvandi, Boham and Gasiorowski,Mark (30October2019) "The United States Overthrew Iran's Last Democratic Leader," Foreign Policy.

Bacevich,Andrew (2020) The Age of Illusions: How America Squandered is Cold War Victory, Metropolitan Books, New York,p.164. 
Bacevich, Andrew (2013), The New American Militarism: How Americans are Seduced by War, Oxford University Press (second edition), p.84.

Avoiding War," in an interview with Amy Goodman, www.democracynow.org.

Benjamin, Daniel and Simon, Steven (November/December 2019) "America's Great Satan: the 40 Year Obsession with Iran," Foreign Affairs, Vol.98, No.6, p.56.

Benjamin, Medea and Davies, Nicolas J.S. (20 May 2020) "Who are the Secret Puppet-Masters Behind Trump's War on Iran," www.commondreams.org.

Bergman, Ronen and Mazetti, Mark (2019) "The Secret History of the Push to Strike Iran," http://www.nytimes.com/2019/09/04/magazine/iran-strike-israel-america.html.

Bulmer-Thomas, Victor (2018) Empire in Retreat: the Past, Present and Future of the United States, Yale University Press p.23.

Dassa Kaye, Dalia and Efron, Shira (August 2020) “Israel's Evolving Iran Policy,” Survival, Vol. 84, Issue 4, p.3.

Dizboni, Ali G. and Omar Sofwat Omar (November (2018), "Hegemonic Aspirations and Middle East Discord: The Case of Iran, Conflict and Diplomacy in the Middle East: External Factors and Regional Rivalry" (editor) Yannis, Stiachtis, E-International Relations Publishing, p.147.

Engelhardt, Tom (2 March 2020) "Best of Tom Dispatch: Chalmers Johnson, Dismantling the Empire," www.TomDispatch.org.

Engelhardt, Tom (2 July2019) "We are not the Good Guys: Why is American Aggression Missing in Action?" www.commondreams.org.

Garner, Kenneth (retrieved 14 January 2020), “Trump Calls the Iranian General QassemSoleimani a 'Son of a Bitch' at Rally," http://nypost.com.

Gasiorowski, Mark J. and Byrne, Malcolm (2004) (editors), Muhammad Mosaddeq and the 1953 Coup in Iran, Syracuse University Press, p.204.

Iran Daily, (September 2019) "Official: Iran-China Trade to Reach \$24b by the End of 2018."

Johnson, Chalmers (2006) Nemesis: The Last Days of the American Republic, Metropolitan Books, p. 58.

Kiriakou, John C, and Gareth Porter (2020) The CIA Insider's Guide to the Iran Crisis, SkyhorsePublishinf, , printed in U.S.A. pp. 18-0.

Kriwaczek, Paul (2002) In Search of Zorathustra: Across Iran and Central Asia to Find the World's First Prophet, Vintage Books, New York, p.10.

Mearsheimer, John J. and Walt, Steven M. (2007) The Israel Lobby and U.S. Foreign Policy,Farrer, Straus Giroux. Porter, Gareth (2014), Manufactured Crisis: The Untold Story of the Iran Nuclear Scare, Just World Books. p.34.

Porter, Patrick (Spring 2018) "Why America's Grand Strategy has not Changed: Power, Habit and the U.S. Foreign Policy Establishment," International Security, Vol. 12, No. 4, p.1.

Ripley, Amanda (24 January 2010) "With Iran, It's About Humiliation," Washington Post, reprinted in The Age, p.23.

Safpukas, Agis (7 March 1995) "Iran Signs Oil Deal with Conoco: First Since 1980s Break with U.S.," The New York Times.

Stone, Oliver (2012) The Untold History of the United States, Simon and Schuster. See also Jeremy Scahill(2013) Dirty Wars : the World is a Battlefield, Nation Books.

Tarock, Adam (2013)"Russo-Iranian Relations in a Post-Soviet Era," Diplomacy and Statecraft, Vol. 28, No. 3.

Tossi, Sina (27 July 2020) “The beginning of the U.S.-Iran Hot War?” www.commondreams.org. 